\title{
Transatlantica
}

Revue d'études américaines. American Studies Journal

\section{Against The Declining Significance of Race}

The Underclass Debate and the History of the African American Working Class from Below

\section{Andrew Diamond}

\section{Q OpenEdition}

1 Journals

\section{Édition électronique}

URL : https://journals.openedition.org/transatlantica/4371

DOI : $10.4000 /$ transatlantica.4371

ISSN : 1765-2766

Éditeur

Association française d'Etudes Américaines (AFEA)

\section{Référence électronique}

Andrew Diamond, «Against The Declining Significance of Race », Transatlantica [En ligne], 1 | 2009, mis en ligne le 03 juillet 2009, consulté le 16 septembre 2021. URL : http://journals.openedition.org/ transatlantica/4371; DOI : https://doi.org/10.4000/transatlantica.4371

Ce document a été généré automatiquement le 16 septembre 2021.

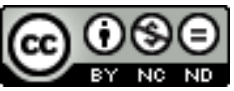

Transatlantica - Revue d'études américaines est mise à disposition selon les termes de la licence Creative Commons Attribution - Pas d'Utilisation Commerciale - Pas de Modification 4.0 International. 


\section{Against The Declining Significance of Race}

The Underclass Debate and the History of the African American Working Class from Below

Andrew Diamond

\section{The Rising Significance of Class}

1 Re-examining William Julius Wilson's landmark study, The Declining Significance of Race today, in a moment quite distant from the book's release context some thirty years ago, it is difficult to understand how this rather brief treatise on "race and class in the American experience" could have played a key role in transforming the research agenda of a generation of scholars working on the history of African Americans in the United States. The book relies almost entirely on preexisting research, much of which had sparked little controversy when it first appeared, as well as rather conventionally derived sets of demographic and socioeconomic data. Moreover, one of its most controversial positions-that black ghetto populations were stricken by a set of problems linked to debilitating patterns of behavior and family instabilities-had been a fixture of urban policy discourse since the publication of the Moynihan Report in 1965. Upon reading the previous sentence, you might well have remarked that I carefully avoided the use of the word "culture": that is because Wilson does as well. In fact, the word "culture" or "cultural" appears but a handful of times in the text, and even then only in the context of Wilson's discussion of the historiographical debate concerning the nature of slave culture, which he summarizes in the book's second chapter. ${ }^{1}$ In the late 1970s, "culture"-especially when used in the company of African Americans-was a term that was overloaded with theoretical, ideological, and political baggage, and Wilson's avoidance of the term was hardly innocent. However, the presence of "culture talk" (to borrow Mahmoud Mamdani's term) in discourses about the black urban poor was so pervasive in the late 1970s and 1980s that "culture" ended up forcing its way into TDSR anyways. ${ }^{2}$ Critics would lose no time in lambasting the 
book for its reiteration of the same "culture of poverty" thinking that the Moynihan Report-with its invocation of a "tangle of pathology" ensnaring the black underclasshad popularized years before. This was a line of reasoning, many argued, that placed the blame for ghetto poverty on underclass blacks themselves rather than the forces of institutional racism that maintained the ghettos they lived in.

Yet Wilson's rendition of the culture of poverty characterizing inner-city black communities, based as it was on the research of others and covering but a handful of pages of a two-hundred page book, cannot alone explain the enormous impact TDSR had on scholars working on the black experience in the 1980s and early 1990s. Perhaps even more provocative than the book's proximity to a culture of poverty rationality was its implicit vision of racial progress-a view captured slogan-like by its straighttalking title. Years later sociologist Herbert Gans commented that Wilson would have "saved himself a lot of trouble" if he had instead called the book "The Rising Significance of Class." Indeed, Wilson's argument that the improving conditions of the black middle class called for a shift away from race and towards class as the framework for both understanding and addressing black underclass poverty placed many African American academics in the humanities and social sciences on the defensive, historians not the least among them. Many of the African American historians who either held positions or were in the process of working towards doctoral degrees when TDSR made its appearance belonged to the first generation of "black studies" scholars, and quite a few among them viewed their careers as a continuation of the struggle for civil rights and black cultural recognition that had retreated from the streets of black America in the early 1970s and established beachheads in colleges and universities throughout the United States. ${ }^{4}$ In the eyes of a good many such researchers, Wilson's work essentially implied that the battle they were fighting had largely been won, that their very professional lives were powerful evidence of this fact, and that, in any case, their efforts could only touch middle class blacks who did not really need their help in the first place. Amplifying the potency of such messages, moreover, was the rather striking embrace of the book and its author by the academic establishment. Indeed, despite its largely derivative and inarguably modest scholarly labor, the American Sociological Association awarded TDSR its prestigious Sydney Spivack Award, thereby setting its author on the road to fame, power, and, by the standards of the academic profession, fortune. Shortly after the publication in 1987 of his next and no less pithily titled book, The Truly Disadvantaged, which sought to deepen the analysis of the ghetto underclass elaborated in TDSR and outline its policy implications, Wilson received the top honor available to scholars-the coveted and lucrative MacArthur Fellowship.

3 The fact that the academic establishment and then the mass media lined up behind such prescriptive research suggests that Wilson was saying something pleasing to the ears of the political center in the United States in the late 1970s and 1980s. Indeed, that Wilson's work had come to define the consensus view on race in the United States was indicated by his need to defend himself against the charge of being a black conservative. Reflecting on criticisms of TDSR coming from left-leaning scholars in the preface of The Truly Disadvantaged, Wilson claimed, "I am a social democrat, and probably to the left politically of an overwhelming majority of these critics." ${ }^{5}$ How it came to be that a self-proclaimed "social democrat" could be mistaken for a conservative in this moment had to do with the prickly issue race had become for the Democratic Party. In the decade that had passed since Richard Nixon had skillfully used 
the politics of white backlash to capture the presidency in 1968, powerful anti-tax and anti-busing revolts by middle class homeowners throughout the Sunbelt South and blue-collar whites in the metropolitan Midwest and Northeast had forced liberals within the Democratic Party to retreat from the principles of racial liberalism. In the election of 1980, Ronald Reagan, who had coined the term "welfare queen" in the previous election, mixed a healthy dose of racially coded, anti-welfare rhetoric with colorblind languages of individual rights to incite the mass defection of "Reagan Democrats" to the Republican Party. Hence, by the early 1980s, Democrats were anxious to turn the page on the divisive racial politics of the past decade, and Wilson's TDSR provided the retreat from racial liberalism with intellectual legitimacy, and, no less important, cultural authenticity. ${ }^{6}$

4 In fact, Wilson's intellectual authority and his cultural authenticity were two sides of the same coin. His emergence in this moment as arguably the most powerful black intellectual in the United States and as the central object of opposition for many historians working on the black experience would probably never have been possible were it not for the fact that he could rightly claim to have passed through the very condition and culture that many of his colleagues-at least from a socioeconomic standpoint-were trying to understand from afar. Wilson's own mother, in fact, had received welfare payments as she struggled to raise her six children in the workingclass town of Blairsville, Pennsylvania after her husband, a coal miner, had died of lung disease. The elite sociologist had indeed once been one of the "truly disadvantaged," a situation that made him dangerous to those who opposed his message. This was not because his life story could be used by race-baiting, anti-welfare ideologues to trumpet a pull-yourself-up-by-your-bootstraps homily, as was the case in 1991 with the Supreme Court nomination of Clarence Thomas. Rather, the power residing in Wilson's authenticity as a former member of the black poor, in terms of its impact on historians and sociologists working on the African American experience, reflected a change in the rules of the game for achieving prestige and authority in the field of black studies-a transformation that Wilson and his provocatively-titled book was helping to bring about.

5 By the time of the publication of TDSR, identity politics had become a force, to one extent or another, in a range of fields in the social sciences and humanities, black studies perhaps the most prominent among them. This happened for two interrelated reasons. First, by the early 1970s, higher education had become a key site in the evolving African American struggle for cultural recognition, with many talented civil rights activists and black radicals finding positions in black studies departments; inspired by the writings of theorists like Frantz Fanon, much of this emerging university-based black intelligentsia became invested in the promotion what Nancy Fraser has called the "identity model" of the politics of recognition-a project that involved African Americans "jettisoning internalized, negative identities and joining together to produce a self-affirming culture of their own." This was a project that, in an ideological conjuncture contoured by residual notions of cultural nationalism and self-empowerment could only be advanced by people of color themselves. Second, seeking to comply with new standards of ethnoracial diversity and cultural sensitivity prevailing in the post-civil rights era, some of the most elite institutions in American higher education began to aggressively recruit minority professors, thereby giving institutional legitimacy to the valorization of racial identities as forms of intellectual and professional authority. ${ }^{8}$ In this context, racial identity-to borrow from the 
theoretical framework elaborated by Pierre Bourdieu-became a powerful form of cultural and symbolic capital within the habitus of American academia, and, more specifically, within the field of black studies. In other words, it endowed its holders with qualifications, competencies, and, most important, the authority to be listened to - provided, of course, the holders were speaking on matters associated with their given identities; moreover, it became a critical (if hardly the only) resource for advancing to positions of power within fields like black studies and African American historypositions which allowed those occupying them to determine the very system within which resources and power within their fields would be distributed in the future. ${ }^{9}$

TDSR made William Julius Wilson a key figure of institutional and intellectual power in his discipline of sociology as well as in the broader field of black studies, but, much more important, the book transformed the modalities of identity politics for African Americans working in the area of black studies. Indeed, rather than diminishing the significance of ethnoracial forms of self-identification among academics, as one might expect from the book's title, TDSR brought another form of symbolic and cultural capital into the habitus of black studies that took on increasing importance throughout the 1980 s and into the 1990s-working-class identity. This was hardly the first time that working-class identity had been fetishized within milieus dominated by middle-class intellectuals. Such was the case in both black radical intellectual circles and within the white New Left student movement beginning in the early 1960s, when the influence of Marxist thought created a fascination with the cultural authenticity and revolutionary potential of the black urban lumpenproletariat. ${ }^{10}$ In fact, such currents entered the academy along with the black and white activists who turned to careers in higher education in the 1970s. Yet, the brand of identity politics that TDSR helped to usher in represented something of an inversion of the 1960s class identity model.

Indeed, in a somewhat ironic twist of fate, it was within the post-civil rights world of academia during the Reagan era that a cohort of organic intellectuals from the black working class-William Julius Wilson, Glenn C. Loury, Thomas Sowell, and Shelby Steele, to name some of the most renowned-was finally able to rise through the ranks and assume key leadership positions in disciplines contributing to the debate on race and the "urban crisis."11 But these spokesmen of the working class were hardly the vanguard of the revolution. Indeed, William Julius Wilson's genuine commitment to social democracy aside, they provided some of the most important intellectual underpinnings of the New Right's attack on racial liberalism and its project to place the issue of individual responsibility at the center of discourse about the urban poor. Whether Wilson liked it or not, he was at the forefront of this movement. As much as he strongly disagreed, for example, with Harvard economist Glenn Loury's supply-side solutions to the problem of ghetto poverty, who could mistake the traces of TDSR in Loury's thinking when he declared to a room full of civil rights veterans at a 1984 meeting of the National Urban Coalition in Washington that "The civil rights movement is over," and then argued that the spread of a vast underclass, the poor performance of black students, the explosion of early unwed pregnancies among blacks, and the high rates of black-on-black crime were all evidence of "fundamental failures in black society." 


\section{Bill Cosby, Willie Horton, and the Truly Dependent}

8 Despite the undeniable proximity of TDSR's analysis of ghetto poverty to the culture of poverty rationale that provided the intellectual underpinnings of the Reagan Revolution's conservative attack on welfare, by the mid 1980s it was clear to most astute observers that Wilson had become something of a victim of circumstances. True, he had failed to distinguish his account of the causes of ghetto poverty from the Republican Party line, but his solutions to the problem were undeniably contradictory to those being proposed by the Reagan Administration and black conservatives like Steele, Sowell, and Loury. Wilson, after all, was not heading for conservative think tanks like Stanford's Hoover Institution, as his peers Sowell and Steele were, or for a position in the Reagan Administration, as Loury was. Yet, Sowell and Loury were economists and Steele a professor of literature; as a sociologist and a self-proclaimed figure of the social democratic left, Wilson remained the most important target for historians, sociologists, and political scientists studying the black ghetto. For the emerging generation of historians working in this area, in particular, TDSR and the anti-welfare politics surrounding it had by the mid 1980s delineated a new theoretical and historiographical project centered on recuperating the sullied, disempowered image of the black working class by illuminating its remarkable political agency in the face of formidable structural constraints. In the early 1990s, Robin D.G. Kelley characterized this new historiographical branch as "African American working-class history 'from below,"' locating its origins at the crossroads of two scholarly traditionsearly studies of slave rebellions and post-emancipation struggles and the school of "new" labor history that began to take shape in the years following the publication of E.P. Thompson's The Making of the English Working Class in $1963 .{ }^{13}$ But the project of writing "history from below" was well underway by the mid 1980s, when a number of graduate students in African American history were working on dissertations that would help to revolutionize the field.

9 The motives for those joining this unfolding project were simultaneously personal, political, and historiographical in nature, and, once again, whether or not imprints of TDSR were overtly present in the manuscripts being produced by scholars working in this vein, the politics surrounding the book often registered on a more personal level. In particular, TDSR's vision of a rising black middle class largely unaffected by the forces of institutional racism provoked scholars who viewed their role in the context of a broader black struggle for cultural recognition. The book's title and thesis had the inevitable effect of drawing attention to the reality that a great many black professors in the academy hailed from middling rather than underclass origins. This was already something of a sensitive issue for the first wave of black studies scholars, a situation indicated by the ultimately unsuccessful struggles waged by many of them to orient their universities towards serving the needs of local black communities. For example, at the University of Chicago, which is located just blocks away from an impoverished ghetto neighborhood, a "community education" campaign was rejected by the school's administration for being incompatible with the ideals of elite education. This was not just the case in the nation's most selective universities; a few miles away from the University of Chicago, a proposal for a masters program in "urban education" at the public, largely working-class Chicago campus of the University of Illinois was shot down by the dean of the College of Education when the program's proponents 
demanded a system of community oversight. ${ }^{14}$ Such campaigns reveal the kinds of frustrations felt by black studies scholars who viewed their role in the university as aligned with the larger black struggle for civil rights and cultural recognition. By the early 1980s, the ties between the professional lives of most black academics and the black working class were becoming more and more attenuated, and Wilson's thinking was further belittling what still remained-the sense of solidarity that came with the shared experience of racial discrimination.

Further exacerbating the gnawing issue of class stratification within the black "community" was the increasing visibility of middle class blacks in American popular culture at the very same time that the Reagan Administration's wars on street gangs, drugs, and welfare were shaping an ideological context that demonized lower-income blacks as gangbangers, drug pushers, and welfare queens. Between 1985 and 1990, for example, the number one rated primetime television show in the United States, The Cosby Show, recounted the lives of an affluent black family named the Huxtables living in a posh brownstone in Brooklyn. This was not some exception, but was part of a general trend that saw the gaze of mainstream America increasingly fixed upon black middle-class subjects. During the same years The Oprah Winfrey show dominated daytime television, purveying a highly integrated, middle class perspective to the country's housewives, while many Americans across the nation eased into their days with the The Today Show's elegant black morning television host, Bryant Gumbel. American popular culture thus seemed to be echoing-perhaps even celebratingWilson's description of an ascendant black middle class, but this hardly meant that the demons of the black ghetto had lost their power to shape racial meanings in the white mind. It was, for instance, the "badman" underclass figure of Willie Horton, a convicted black murder who had raped a white woman while out on furlough from prison, that supplied Republican candidate George Bush Sr.'s campaign with its most powerful liberal-bashing weapon, helping him to overcome a double-digit deficit in the polls in the final weeks preceding the 1988 election.

11 This was the political and cultural backdrop in the United States during the mid 1980s, when the Reagan Administration's project to reform the country's welfare system launched a debate over the causes of inner-city poverty and ghettoization. In fact, as certain as the Reagan Administration and its New Right ideologues were about the fact that welfare caused dependency and ultimately poverty, the 1986 report of the Working Group appointed by the President to study the matter, predictably entitled Up from Dependency, seemed to be issuing a clarion call for research and debate on the problem of urban poverty when it recommended that national welfare efforts be replaced by state and community-based programs "until this country better knows what both relieves poverty and reduces dependency." 15 This report revealed several important dimensions of the debate over welfare reform and urban poverty. First, it demonstrated just how important the welfare reform issue had become to conservative politics; in the midst of skyrocketing military spending and a barrage of supply-side economic policies that were working to dramatically redistribute capital upward, the Reagan Administration was placing the scaling down of the federal government's comparatively minuscule expenditures on welfare programs at its moral center. Second, it highlighted how much welfare dependency had become the explanation for urban poverty, and how much this link depended upon the construction of black ghetto culture as pathological. Finally, it revealed that the impressive gains made by African American scholars in the world of academia in the 1970s and 1980s had been of 
relatively little use in counteracting the processes through which the black working class-at that time usually referred to as the "underclass"-became equated with some combination of criminal, loser and welfare dependent in the white mind.

\section{Empowering the Disempowered and the Nihilistic}

Hence, as a result of circumstances that had as much to with his perceived "positionality" as his depiction of ghetto culture, William Julius Wilson played a key role in the rhetorical shift that made an "underclass" out of lower-income African Americans during the $1980 \mathrm{~s} .{ }^{16} \mathrm{And}$, it is for this reason, more than the doubts he raised about the "significance" of racial discrimination, that Wilson became a critical negative reference point for the developing project of black working-class history from below. For historians moving into this camp during the 1980s, the challenge was not so much about reaffirming the role played by race and racism in the lives of average black folks, but rather restoring the vitality and agency of the black working class. The historical profession, in particular, had found itself almost completely unprepared for the underclass debate of the early 1980s. For one thing, historical research on the postWorld War II black ghetto was virtually nonexistent until the publication of James Borchert's Alley Life in Washington: Family, Community, Religion, and Folklife in the City, 1850-1970 and Arnold Hirsch's Making the Second: Race and Housing in Chicago, 1940-1960 in 1982 and 1983. In fact, up until that time, the historiography of the black experience in the twentieth century city was largely limited to a number of fine monographs on black ghettos between the 1890s and the 1930s-a scholarly literature that Joe William Trotter has called the "ghetto synthesis." ${ }^{17}$ That most of the "ghetto synthesis" studies leave off before the highly transformative Second Great Migration of African Americans to the North in the 1940s and 1950s was only part of the problem; no less problematic for the use of such scholarship in challenging the underclass vision of a disempowered, oppressed black working class was its interpretive bent, which emphasizes the forces of grassroots and institutional racism in the process of ghetto formation. Even Hirsch's pathbreaking book, the first major monograph to push the ghetto formation story past the 1930s, while offering a much more sophisticated view of the dynamics of white hostility and violence at the edges of the ghetto, presents a rather one-dimensional view of African Americans as being acted upon rather than mobilizing to defend and empower themselves in the face of such circumstances. ${ }^{18}$

It was not until 1985 that one could begin to see the tangible fruits of an African American working-class history from below within the historical profession with the publication of Joe Trotter's Black Milwaukee: The Making of an Industrial Proletariat, 1915-45. Employing what its author refers to as a "proletarianization model" to examine how black industrial workers developed both class and racial consciousness in their experiences in the workplaces and neighborhoods of Milwaukee, Black Milwaukee marked a powerful departure from the "ghetto synthesis" literature. As Kenneth Goings and Raymond Mohl argued more than a decade later, in its presentation of "people empowered, engaged in struggle, living their lives in dignity, and shaping their own futures," Black Milwaukee became the seminal text in what they called the "New African American Urban History." 19 Such references to "empowerment," "struggle," and "dignity" as foundational concepts in the historiography of the twentieth-century black urban experience indicate the extent to which TDSR and the underclass debate it 
shaped helped to regenerate the field of African American history in the 1980s. As the first historian in this area to draw a strong connection between his project and the work of labor historians like Herbert Gutman and David Montgomery, Trotter was somewhat ahead of his time, but his work inspired the research of a number of young scholars conducting research, working on dissertations, and revising manuscripts who had, by the early 1990s, remade the history of the black working class from belowhistorians like Robin Kelley, Earl Lewis, Michael Honey, Eric Arnesen, and Bruce Nelson. 20

Yet, among those constituting this talented cohort, it was Robin D.G. Kelley who most effectively brought his research to bear upon the continuing underclass debate of the early 1990s, and he did so because he understood that culture had become the new battlefield in the war over the past and present of the black working class. Working within a theoretical framework informed by the new labor history, British cultural theorists like Stuart Hall and Paul Gilroy, and the work of anthropologist James C. Scott on peasant resistance in Southeast Asia, Kelley powerfully excavated the agency of working-class blacks in the spheres of leisure and everyday life. In a direct challenge to culture of poverty arguments that trafficked in images of ghetto immorality and nihilism, Kelley demonstrated that a "dissident political culture" existed in places where most historians, sociologists, political scientists, and policy analysts had never even thought to look-on buses and street corners and in bars, poolrooms, barber shops, and dance halls. By the time Kelley's work was published in collected form in 1994 in Race Rebels: Culture, Politics, and Black Working Class, William Julius Wilson no longer held quite the same meaning for historians working on African American working-class history. ${ }^{21}$ While Kelley makes sure to point out how his work challenges "William Wilson's hypothesis that the 'underclass' is socially isolated from and indifferent toward political institutions," much of his scholarly labor is directed at the prevailing view of the black working class as nihilistic. ${ }^{22}$ Indeed, eclipsing Wilson around 1994 was another ambiguous figure of the left, Cornell West, who ascended to the heights of American higher education with his vision of a profound sense of nihilism pervading inner-city black communities. ${ }^{23}$ By then the Republicans had lost the White House but they held Congress, and a Democratic President named William Jefferson Clinton would soon sign a law that would "end welfare as we know it." However, as illuminating and important as Kelley's work was, the broader project it advanced was tied to a politics of identity and recognition that, in the context of the Clinton years, increasingly began to seem ineffective and perhaps even counterproductive. This was not only due to the complicity of the Democrats in dismantling the welfare state during a period of economic prosperity, a move that drew sharp criticism from labor and organizations representing women, minorities, and immigrants. The Los Angeles race riot of 1992 also had a powerful impact on those who placed questions of cultural resistance and racial identity high on the agenda. For one thing, the spectacle of Rodney King's savage beating at the hands of four Los Angeles police officers followed by the breathtaking circumstances of the officers' acquittal by a jury consisting of ten whites, one Latino, and one Asian American seemed to challenge scholars who emphasized cultural resistance and agency at the expense of power and structure. Moreover, the evolution of the uprising in Los Angeles from a rebellion against racial injustice into a war of communities opposing black, Asian, Latino, and white shook the foundations of the "identity model" of the politics of recognition that many of these same scholars tacitly or explicitly clung to. In the wake of such events, 
William Julius Wilson's message, which had not changed all that considerably since its first appearance in printed form in TDSR, sounded quite different. In the political conjuncture of the mid 1990s, it became difficult for anyone claiming some place on the left of the political spectrum to criticize what Wilson was advocating-a massive, WPAstyle investment in inner-city ghettos, suburban-urban consolidation, and a mix of race-based and race-neutral policies that would avoid creating competition between ethnoracial communities.

\section{NOTES}

1. William Julius Wilson, The Declining Significance of Race: Blacks and Changing American Institutions (Chicago: University of Chicago Press, 1978), 34-36.

2. Mahmoud Mamdani, Good Muslim, Bad Muslim: America, the Cold War, and the Roots of Terror (New York: Pantheon, 2004).

3. David Remnick, "Doctor Wilson's Neighborhood," The New Yorker (April 29-May 6, 1996), 100.

4. Historians possessed a key position in the early black studies movement, constituting nearly 20 percent of all scholars in black studies department by the late 1980s: Fabio Rojas, From Black Power to Black Studies: How a Radical Social Movement Became an Academic Discipline (Baltimore: Johns Hopkins University Press, 2007), 186.

5. William Julius Wilson, The Truly Disadvantaged: The Inner City, the Underclass, and Public Policy (Chicago: University of Chicago Press, 1987), viii.

6. For a similar argument, see Stephen Steinberg, "The Liberal Retreat From Race," New Politics 5

(1) (Summer 1995), 30-51.

7. Nancy Fraser, "Rethinking Recognition," New Left Review 3 (May-June, 2000), 110.

8. The top eight universities from which black studies professors earned degrees during the 1970s and 1980s were as follows: the University of Michigan, Yale, Columbia, UCLA, UC Berkeley, Stanford, the University of Chicago, and Harvard (Rojas, From Black Power to Black Studies, 188).

9. Bourdieu applied this theoretical framework to the fields of journalism, literary production, and academia. For his analysis of French higher education, see Pierre Bourdieu, Homo Academicus, trans. Peter Collier, (Stanford, CA: Stanford University Press, 1988). While some have sought to transfer his thinking to the context of higher education in the United States, few have used it to think in any kind of rigorous way about the role of identity politics in the habitus of American academia in the 1980s and 1990s. For a general introduction to Bourdieu's work, see Pierre Bourdieu and Loic Wacquant, An Invitation to Reflexive Sociology (Chicago: University of Chicago Press, 1992).

10. For an excellent discussion on the emergence of such thinking among black "petit bourgeois" radicals, see Robin D.G. Kelley, Freedom Dreams: The Black Radical Imagination (Boston: Beacon Press, 2002), 84-90. The most striking example of the key role played by the politics of class identity within the New Left was the Economic Research and Action Program (ERAP) undertaken by SDS in 1963 and 1964; for a detailed account of such dynamics, see Jennifer Frost, "An Interracial Movement of the Poor": Community Organizing and the New Left in the 1960s (New York: New York University Press, 2001), 110-118.

11. Though not technically an academic, Supreme Court Justice Clarence Thomas should also be considered part of this cohort. 
12. Adam Shatz, "About Face," New York Times Magazine, January 20, 2002. This argument appeared in published form that same year in: Glenn Loury, "A New American Dilemma," The New Republic, December 31, 1984.

13. Robin D.G. Kelley, Race Rebels: Culture, Politics, and the Black Working Class (New York: The Free Press, 1994), 5, 230. For some of the seminal texts on the history of slave resistance and emancipation, see W.E.B DuBois, Black Reconstruction in America: An Essay toward a History of the Part Which Black Folk Played in the Attempt to Reconstruct Democracy in America, 1860-1880 (New York: Harcourt Brace, 1935); C.L.R. James, Black Jacobins: Toussaint L'Ouverture and the San Domingo Revolution, $2^{\text {nd }}$ ed. (New York: Vintage Books, 1963); Herbert Aptheker, American Negro Slave Revolts (New York: International Publishers, 1943). For the foundational works in the new labor history, see E.P. Thompson, The Making of the English Working Class (New York: Vintage Books, 1963); Herbert Gutman, Work, Culture, and Society in Industrializing America: Essays in American WorkingClass and Social History (New York: Knopf, 1976); David Montgomery, Workers Control in America: Studies in the History of Work, Technology, and Labor Struggles (Cambridge and New York: Cambridge University Press, 1979).

14. Rojas, From Black Power to Black Studies, 100-108.

15. Up from Dependency: A New National Public Assistance Strategy (White House Domestic Policy Council, 1986).

16. "Positionality" is a term employed by Michael Awkward to theorize how scholars define their theoretical and professional positions according to their given social identities: see, Michael Awkward, Negotiating Difference: Race, Gender, and the Politics of Positionality (Chicago: University of Chicago Press, 1995).

17. Joe William Trotter Jr., discusses this historiography in Appendix 7 of Black Milwaukee: The Making of an Industrial Proletariat, 1915-45 (Urbana: University of Illinois Press, 1985). The more influential "ghetto synthesis" works are: Gilbert Osofsky, Harlem: The Making of a Ghetto, 1890-1930 (New York: Harper, 1971); Allan Spear, Black Chicago: The Making of a Negro Ghetto, 1890-1920 (Chicago: University of Chicago Press, 1967); Kenneth Kusmer, A Ghetto Takes Shape: Black Cleveland, 1870-1930 (Urbana: University of Illinois Press, 1976); Thomas Philpott, The Slum and the Ghetto: Neighborhood Deterioration and Middle-Class Reform, Chicago, 1880-1930 (New York: Oxford University Press, 1978); James Borchert, Alley Life in Washington: Family, Community, Religion, and Folklife in the City, 1850-1970 (Urbana: University of Illinois Press, 1980); Arnold R. Hirsch, Making the Second Ghetto: Race and Housing in Chicago, 1940-1960 (Cambridge, UK: Cambridge University Press, 1983).

18. For a similar argument about Hirsch and the "ghetto synthesis," see Roger Biles, "Black Milwaukee and the Ghetto Synthesis," Journal of Urban History 33 (May 2007), 539-543. As Biles points out, some works in the "ghetto synthesis" school were able to paint a more nuanced picture of black life, but for the most part they "denied African American agency."

19. Kenneth W. Goings and Raymond A. Mohl, eds., The New African American Urban History (Thousand Oaks, CA: Sage, 1996) as cited in Biles, "Black Milwaukee and the Ghetto Synthesis," 542.

20. See, for example, Robin D. G. Kelley, Hammer and Hoe: Alabama Communists during the Great Depression (Chapel Hill: University of North Carolina Press, 1990); Earl Lewis, In Their Own Interests: Race, Class, and Power in Twentieth-Century Norfolk, Virginia (Berkeley and Los Angeles: University of California Press, 1991); Michael Honey, Southern Labor and Black Civil Rights: Organizing Memphis Workers (Urbana: University of Illinois Press, 1993); Eric Arnesen, Waterfront Workers of New Orleans: Race, Class, and Politics, 1863-1923 (New York: Oxford University Press, 1991); Bruce Nelson, "Class and Race in the Crescent City: The ILWU, from San Francisco to New Orleans," in The CIO's Left-led Unions, ed., Steven Rosswurm (New Brunswick, NJ: Rutgers University Press, 1992), 19-45.

21. Robin D.G. Kelley, Race Rebels: Culture, Politics, and the Black Working Class (New York: Free Press, 1994). 
22. Ibid, 99.

23. Cornell West, Race Matters (Boston: Beacon Press, 1993).

\section{AUTEUR}

\section{ANDREW DIAMOND}

Andrew Diamond is maître de conférences in American history and civilization at the Université Charles de Gaulle - Lille 3. He is the author of Mean Streets: Chicago Youths and the Everyday Struggle for Empowerment in the Multiracial City, 1908-1969 (Berkeley and Los Angeles: University of California Press, 2009), and numerous articles on race and political culture in the postwar metropolitan US. He is currently co-writing a book-length history of Chicago with Pap Ndiaye to be published by Fayard in 2010, and working on a project on cultural racism and the politics of racial diversity in the neoliberal metropolis between the 1960s and the 1990s. 